\title{
Mega-sporting Events as Experience Goods
}

\author{
Malte Heyne ${ }^{\dagger}$,Wolfgang Maennig ${ }^{\dagger \dagger}$, and Bernd Süssmuth ${ }^{\dagger+\dagger}$
}

April 2007

\begin{abstract}
This paper tests the hypothesis that a nation's hosting of a mega-sporting event is an experience good for its residents. Applying data from an ex-ante and ex-post query based on contingent valuation methods, we use the Soccer World Cup 2006 as a natural experiment. The significant ex-post increase in valuation is shown to be due to adventitious citizens requiring an involving experience, rather than to an updating of a-prior assessment.
\end{abstract}

JEL Classification Codes: L83, Q26, H49

Keywords: Experience goods, contingent valuation method, World Cup

This paper is also available as University of Hamburg Working Paper Series in Economic Policy, Number 05/2007.

${ }^{\dagger}$ University of Bremen

${ }^{\dagger+}$ University of Hamburg, Chair for Economic Policy, Von-Melle-Park 5, 20146 Hamburg, Germany, phone: +49 (0)40 42838 - 4622, fax: +49 (0)40 42838 - 6251, E-mail: maennig@econ.uni-hamburg.de

${ }^{+1+}$ Department of Business and Economics, TUM Munich University of Technology, Arcisstr. 21, D-80333 Munich Germany, phone: +49 89289 25709, E-mail: suessmuth@wi.tum.de 


\title{
Mega-sporting Events as Experience Goods
}

\author{
Malte HEYNE \\ University of Bremen
}

\author{
Wolfgang MAENNIG \\ Bernd SÜSSMUTH \\ University of Hamburg Munich University of Technology*
}

\begin{abstract}
This paper tests the hypothesis that a nation's hosting of a mega-sporting event is an experience good for its residents. Applying data from an ex-ante and ex-post query based on contingent valuation methods, we use the Soccer World Cup 2006 as a natural experiment. The significant ex-post increase in valuation is shown to be due to adventitious citizens requiring an involving experience, rather than to an updating of aprior assessment.
\end{abstract}

Keywords: Experience goods, contingent valuation method, World Cup

JEL Codes: L83, Q26, H49

\footnotetext{
*Correspondence:

Department of Business and Economics

TUM Munich University of Technology

Arcisstr. 21, D-80333 Munich

Germany

++498928925709

suessmuth@wi.tum.de
} 


\section{Introduction}

Mega-sporting events like the Olympics, the Soccer World Cup (SWC) finals, or the Super Bowl attract the attention of a myriad of people, implying a variety of potential economic externalities. Baade and Dye (1988), Baim (1994), Kang and Perdue (1994), Teigland (1999), Coates and Humphreys (1999, 2003), Baade and Matheson (2000, 2004), Szymanski (2002), Hotchkiss et al. (2003) test for positive pecuniary economic effects of sport events or sport stadiums. Coates and Humphreys (2003) give a comprehensive survey of both economic impact studies assessing the pecuniary benefits and studies devoted to the non-pecuniary or "consumption" benefits to residents of the host countries.

Recently, another strand of literature emanated from cultural and environmental economics. It is concerned with the quantification of intangible economic ramifications of subsidized (public) goods such as the hosting of Major League teams, the Olympics, and the construction of stadiums in a city (Johnson and Whitehead 2000, Johnson et al. 2001, eftec 2005). This young body of literature adheres to the Contingent Valuation Method (CVM). It assesses positive externalities that are not directly internalized by the market by quantifying the corresponding willingness-to-pay (WTP) of the concerned taxpayers (Arrow et al. 1993).

To our knowledge the notion of experience goods - those for which consumers cannot assess use value in advance but only upon consumption or from past experience (Nelson 1970, van der Ploeg 2002) - has not yet been empirically investigated in relation to CVM or sports, although von Ungern-Sternberg and von Weizsäcker (1985, p. 534) suggested two decades ago that this be done. 
Our study contributes to the literature in the following points. First, it offers an independent ${ }^{1}$ and representative CVM-based quantification of the German population's WTP for hosting the 2006 SWC finals. Secondly, it unravels the nation's assessments of intangibles before and after the event. ${ }^{2}$ Central determinants such as age and educational background are identified using censored regression models. Finally, our interpretation of the hosting of the SWC as an experience good opens a new perspective in the economic evaluation of mega-sporting events.

\section{Data and Empirical Approach}

Three months prior to and three months after the 2006 SWC finals in Germany, that is, in March and October, we conducted two online surveys. Our sample consists of 500 individuals. ${ }^{3}$ They are drawn from the ComCult Online Panel which is stratified by TNS Emnid, one of Germany's leading institutes in social science survey research. It is a representative sample for the German population aged 14 to 70 .

In the quarter prior to the start of the tournament the subjects were confronted with the following counterfactual scenario: "Suppose that shortly before the beginning of the cup finals, severe doubts on security issues with regard to stadium construction and potential terrorist attacks are raised. Given the current status of security, the threat of terrorism is comparable in scale to that at the 1972 Olympics in Munich. Therefore, the FIFA is tending toward relocating the cup finals to Switzerland, where an ideal

\footnotetext{
${ }^{1}$ This does, for example, not apply to eftec (2005). For a critique of commissioned and frequently upward biased economic impact studies see Coates and Humphreys (2003, p. 339).

${ }^{2}$ While Baade and Matheson (2004) is an example for a retrospective study, the eftec (2005) CVM analysis of the London 2012 Olympics clearly is of the ex-ante type.
} 
infrastructure is ready to stage the matches thanks to early and thorough preparation of the Swiss co-hosting of the 2008 European Cup finals. There is still a chance that the tournament will take place in Germany, but only if a series of costly safety measures are adopted. However, these previously unplanned measures can only be financed with immediate voluntary contributions from the population. Would you personally be willing to contribute some of your own money to ensure the finals can be hosted in your home country?

A quarter of a year after the Cup, the same persons were asked: "About six months ago you were asked in a counterfactual scenario about your willingness-to-pay for your home country to host the SWC finals. Now that you experienced it, imagine yourself back in March: Would you change your mind and/or adjust the amount you would be willing to pay?”

\section{Findings and Estimates}

Overall, we find that ex ante less than every fifth German has a positive WTP. However, after the event $42.6 \%$ of the population report a positive WTP. The corresponding increase is $129 \%$. In sum, $26.6 \%$ of subjects changed their mind; $14.2 \%$ of these decreased their WTP, 85.5\% increased it.

The average ex-ante WTP for the whole sample is €4.26 per person, which gives a total mean WTP of €351.5m for a total population of 82.5 million Germans. The average ex-ante WTP for individuals with a strictly positive WTP is €22.90. The average ex-post WTP for the whole sample is $€ 10.07$ per person, which gives a total mean WTP of

\footnotetext{
${ }^{3}$ Sixteen respondents of the ex-ante survey (3.2\%) did not participate in the ex-post survey. We treat them as sticking to their ex-ante valuation. Notably, our results do not change qualitatively if we drop these
} 
$€ 830.78 \mathrm{~m}$. The average ex-post WTP of test persons with a WTP $>0$ is €23.62. The average change in WTP is positive and amounts to €6.00. For the total population it is a substantial €495m.

Notably, there is a relatively small change of 72 cents in average WTP for the sub-sample of subjects with a WTP $>0$. The substantial increase in overall WTP can be attributed to persons reporting a zero WTP ex ante and a positive ex-post WTP after experiencing the event. Who are these subjects?

Residents have an expected heterogeneous benefit from the national hosting (Table 1). They also face an individual shadow price of avoidable costs in case of relocation. This weighing-up against the reservation position depends on characteristics like age (AGE), educational level (EDU), gender (MALE), region (BERLIN, EAST), and employment status (WORK). If this propensity is correlated with the actual value (WTP), a selectivity problem arises. We use the two-step Heckit to test and account for it. The discrete choice decision is identified by AGE and BENEFIT. The latter is a dummy of whether a respondent sees an overall benefit for Germany or not. A corresponding question has been part of the survey.

Selectivity is only relevant for explaining the final WTP. It does not matter for the ex-ante WTP and the change in WTP. This suggests looking at the respective Tobit models that we censored left ( 0 for WTP1 and -70 for $\Delta \mathrm{WTP}$ ) and right (70) due to $€ 70$ being the upper WTP-threshold in our survey. While the educational level has a sizable, positive, and statistically significant impact on WTP1, it impacts negatively on $\triangle \mathrm{WTP}$, though to a lesser extent. This allows the interpretation that it was primarily the less

individuals from the sample. 
educated who changed their WTP after the tournament. In the vast majority of cases, they did so from a zero value to a WTP $>0$. However, this behavior is even more pronounced for residents of eastern Germany. A change in WTP is also positively dependent on whether an individual has a job or not (WORK). In nearly all specifications, age is negatively related to WTP and change in WTP.

In sum, we find two intriguing facts and evidence in favor of an experience goods character: First, the lion's share, i.e. 88\%, of the ex-post increase in valuation of roughly $€ 0.5$ bn can be attributed to adventitious contributors to the aggregate WTP (with zero exante WTP) rather than to a basic updating of the individual ex-ante WTP. Second, because it is relatively difficult to assess the intangibles involved in staging a megasporting event, residents with a lower educational level require experience for their valuation. The latter also holds for citizens from regions of the former GDR due to their lack of past experience.

\section{Conclusion}

This is a first test of whether mega-sporting events can be identified as experience goods for residents of the host country. According to our findings, CVM-studies - including studies from a cultural or environmental background - that ignore a potential experience good character might suffer from a downward-bias. 


\section{References}

Arrow, K., Solow, R., Portney, P., Leamer, E., Radner, R., and H. Schuman. 1993. Report of the NOAA Panel on Contingent Valuation. Federal Register 58, 46014614.

Baade, R. A. and R. F. Dye. 1988. An Analysis of the Economic Rationale for Public Subsidization of Sports Stadiums. Annals of Regional Science 22, 37-47.

Baade, R. A. and V. A. Matheson. 2000. An Assessment of the Economic Impact of the American Football Championship, the Super Bowl, on Host Communities. Reflets et Perspectives 39, 35-46.

--_- 2004. The Quest for the Cup: Assessing the Economic Impact of the World Cup. Regional Studies 38, 343-354.

Baim, D. V. 1994. The Sports Stadium as a Municipal Investment. Westport (Conn.): Greenwood Press.

Coates, D. and B. R. Humphreys. 1999. The Growth Effects of Sport Franchises, Stadia, and Arenas. Journal of Policy Analysis and Management 18, 601-624.

-_--. 2003. Professional Sports Facilities, Franchises and Urban Economic Development. Public Finance and Management 3, 335-357.

eftec. 2005. Olympic Games Impact Study - Stated Preferences Analysis. Final Report for the Department of Culture, Media and Sport, London.

Hotchkiss, J., Moore, R. E., and S. M. Zobey. 2003. Impact of the 1996 Summer Olympic Games on Employment and Wages in Georgia. Southern Economic Journal 69, 691-704.

Johnson, B. K. and J. C. Whitehead. 2000. Value of Public Goods From Sports Stadiums: The CVM Approach. Contemporary Economic Policy 18, 48-58.

Johnson, B. K.; Groothuis, P. A.; and J. C. Whitehead. 2001. The Value of Public Goods Generated by a Major League Sports Team: The CVM Approach. Journal of Sports Economics 2, 6-21. 
Kang, Y.-S. and R. Perdue. 1994. Long-Term Impact of a Mega-Event on International Tourism to the Host Country: A Conceptual Model and the Case of the 1988 Seoul Olympics. Journal of International Consumer Marketing 6, 205-225.

Nelson, P. 1970. Information and Consumer Behavior. Journal of Political Economy 78, 311-329.

Ploeg, R. van der. 2002. In Art We Trust. De Economist 150, 333-362.

Szymanski, S. 2002. The Economic Impact of the World Cup. World Economics 3, 169177.

Teigland, J. 1999. Mega-Events and Impacts on Tourism: The Predictions and Realities of the Lillehammer Olympics. Impact Assessment and Project Appraisal 17, 305317.

Ungern-Sternberg, T. von and C. C. von Weizsäcker. 1985. The Supply of Quality on a Market for “Experience Goods”. Journal of Industrial Economics 33, 531-540. 
Table 1. Censored regression models

\begin{tabular}{|c|c|c|c|c|c|c|c|c|c|}
\hline & \multicolumn{6}{|c|}{ HECKIT Models } & \multicolumn{3}{|c|}{ TOBIT Models } \\
\hline & $\begin{array}{c}\text { WTP1 } \\
\text { indicator }\end{array}$ & $\begin{array}{l}\text { WTP1 } \\
\text { amount }\end{array}$ & $\begin{array}{c}\text { WTP2 } \\
\text { indicator }\end{array}$ & $\begin{array}{l}\text { WTP2 } \\
\text { amount }\end{array}$ & $\begin{array}{c}\Delta \mathrm{WTP} \\
\text { indicator }\end{array}$ & $\begin{array}{l}\Delta \mathrm{WTP} \\
\text { amount }\end{array}$ & WTP1 & WTP2 & $\Delta \mathrm{WTP}$ \\
\hline BENEFIT & $\begin{array}{c}0.719^{* * *} \\
(3.03)\end{array}$ & & $\begin{array}{c}0.491^{* * *} \\
(2.93)\end{array}$ & & $\begin{array}{c}0.350^{* *} \\
(3.03)\end{array}$ & & $\begin{array}{c}30.892^{* * *} \\
(2.76)\end{array}$ & $\begin{array}{c}17.662^{* * *} \\
(3.17)\end{array}$ & $\begin{array}{c}3.247 \\
(1.46)\end{array}$ \\
\hline AGE & $\begin{array}{c}-0.007^{*} \\
(-1.65)\end{array}$ & & $\begin{array}{c}-0.014^{* * *} \\
(-3.79)\end{array}$ & & $\begin{array}{c}-0.017^{* * *} \\
(-4.56)\end{array}$ & & $\begin{array}{c}-0.280 \\
(-1.36)\end{array}$ & $\begin{array}{c}-0.490^{* * *} \\
(-4.00)\end{array}$ & $\begin{array}{c}-0.150^{* * *} \\
(-2.86)\end{array}$ \\
\hline EDU & $\begin{array}{c}0.157^{* * *} \\
(2.46)\end{array}$ & $\begin{array}{l}1.957 \\
(0.87)\end{array}$ & $\begin{array}{c}0.056 \\
(0.99)\end{array}$ & $\begin{array}{c}-1.735 \\
(-1.12)\end{array}$ & $\begin{array}{l}0.070 \\
(1.23)\end{array}$ & $\begin{array}{c}-4.822^{* *} \\
(-2.26)\end{array}$ & $\begin{array}{c}7.890^{* * *} \\
(2.63)\end{array}$ & $\begin{array}{c}0.463 \\
(0.23)\end{array}$ & $\begin{array}{c}-1.667^{* *} \\
(-2.06)\end{array}$ \\
\hline MALE & $\begin{array}{c}-0.036 \\
(-0.26)\end{array}$ & $\begin{array}{c}8.638^{* *} \\
(1.95)\end{array}$ & $\begin{array}{c}0.252^{* *} \\
(2.18)\end{array}$ & $\begin{array}{c}1.983 \\
(0.59)\end{array}$ & $\begin{array}{c}0.224^{*} \\
(1.91)\end{array}$ & $\begin{array}{c}2.060 \\
(0.47)\end{array}$ & $\begin{array}{c}2.853 \\
(0.47)\end{array}$ & $\begin{array}{c}9.212^{* *} \\
(2.53)\end{array}$ & $\begin{array}{c}2.275 \\
(1.43)\end{array}$ \\
\hline BERLIN & & $\underset{(-1.73)}{-11.309^{*}}$ & & $\begin{array}{c}-5.677 \\
(-0.67)\end{array}$ & & $\begin{array}{c}-0.160 \\
(-0.01)\end{array}$ & $\begin{array}{c}-8.187 \\
(-0.51)\end{array}$ & $\begin{array}{c}-6.627 \\
(-0.76)\end{array}$ & $\begin{array}{c}-1.595 \\
(-0.43)\end{array}$ \\
\hline EAST & & $\begin{array}{c}-2.141 \\
(-0.40)\end{array}$ & & $\begin{array}{c}8.243^{* *} \\
(1.89)\end{array}$ & & $\begin{array}{c}10.672^{* *} \\
(2.24)\end{array}$ & $\begin{array}{c}-10.489 \\
(-1.21)\end{array}$ & $\begin{array}{c}3.633 \\
(0.74)\end{array}$ & $\begin{array}{c}4.644^{* *} \\
(2.14)\end{array}$ \\
\hline WORK & & $\begin{array}{c}-2.718 \\
(-0.63)\end{array}$ & & $\begin{array}{c}3.226 \\
(1.02)\end{array}$ & & $\begin{array}{c}6.389 \\
(1.52)\end{array}$ & $\begin{array}{c}-0.773 \\
(-0.12)\end{array}$ & $\begin{array}{c}5.780 \\
(1.54)\end{array}$ & $\begin{array}{c}3.255^{* *} \\
(1.98)\end{array}$ \\
\hline$\lambda / 100$ & & $\begin{array}{c}-296.58 \\
(-1.19)\end{array}$ & & $\begin{array}{c}-36.35^{*} \\
(-1.79)\end{array}$ & & $\begin{array}{c}-21.00 \\
(-0.97)\end{array}$ & & & \\
\hline$-\ln \mathrm{L}$ & 230.0 & 411.5 & 324.2 & 936.3 & 311.0 & 843.3 & 584.3 & 1170.0 & 2105.6 \\
\hline
\end{tabular}

WTP1 - ex-ante WTP, WTP2 - ex-post WTP, $\triangle \mathrm{WTP}$ = (WTP2-WTP1), 'indicator' refers to 0/1 decision (Heckit Step I: Binary Probit); 'amount' refers to actual amount $\in[0,70]$ or $\in[-70,70]$ (Heckit Step II); *, **, *** denotes significance at 10, 5, 1\% level; all estimates include a constant; values in parentheses give $z$-statistics for the censored models, else they represent corrected $t$-statistics; $\lambda$ denotes the inverse Mill's Ratio. 